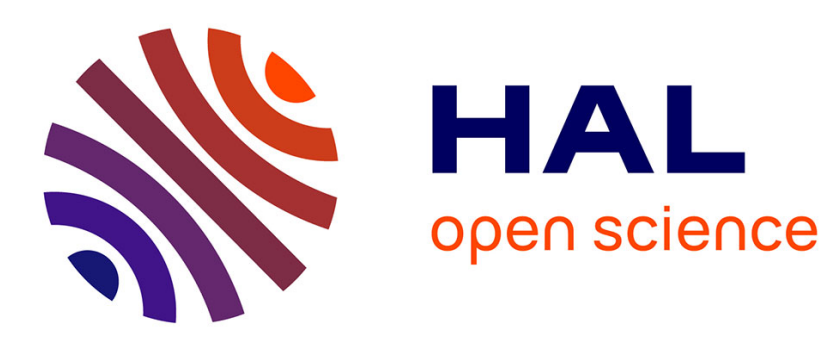

\title{
The Municipality of Salonica between Old Regime, the Ottoman Reforms and the Transition from Empire to Nation State
}

Nora Lafi

\section{- To cite this version:}

Nora Lafi. The Municipality of Salonica between Old Regime, the Ottoman Reforms and the Transition from Empire to Nation State. Dimitris Keridis, John Brady Kiesling. Thessaloniki: A City in Transition (1912-2012), Routledge, p.81-94, 2020, 9780367192822. halshs-00981804

\section{HAL Id: halshs-00981804 \\ https://shs.hal.science/halshs-00981804}

Submitted on 22 Apr 2014

HAL is a multi-disciplinary open access archive for the deposit and dissemination of scientific research documents, whether they are published or not. The documents may come from teaching and research institutions in France or abroad, or from public or private research centers.
L'archive ouverte pluridisciplinaire HAL, est destinée au dépôt et à la diffusion de documents scientifiques de niveau recherche, publiés ou non, émanant des établissements d'enseignement et de recherche français ou étrangers, des laboratoires publics ou privés. 


\title{
The Municipality of Salonica between Old Regime, the Ottoman Reforms and the Transition from Empire to Nation State: Questions and Research Perspectives
}

\author{
Nora Lafi (ZMO-BMBF, Berlin)
}

\section{Introduction}

The history of Thessaloniki (or Salonica, Selânîk) is now well-documented: many aspects of urban life during the last decades of the Ottoman Empire and during the transition to Greek sovereignty have been explored and the image we have of the history of the city is now much more nuanced than a few decades ago. Historiography, however, often remains quite splintered between various sectors which are not always corresponding to a common sphere of questionings and of scholarly dialogue. From the history of the Jews in the city to the general history of the Ottoman Empire between reforms and Balkan Wars ${ }^{1}$, or to the history of national struggles in the region and to that of the city at the time of its integration into the Greek kingdom, Thessaloniki tends to be the object of separate historiographical traditions, questionings and methods. All have profoundly evolved during recent decades, but not necessarily converged. It is of course a matter of competences, for historians working on different periods and archival resources of different nature and languages. But it is also a question linked to the very sociological milieu of historians, with its divides, its schools of interpretation and its own diversity of points of view. The question of the historiography of Thessaloniki indeed remains a highly ideological one, with different traditions corresponding to different interpretations of history. Even if the era of national historiographies is now largely over, or at least the object of critical examinations, history writing about and on Thessaloniki is far from being the object of a consensus. Divergent views on the Ottoman period continue for example to characterize the narratives of the city. But the context is quite favourable for a new discussion: on the one side, the Greek nationalist narrative has now been nuanced, and on the other side, studies on cosmopolitan Salonica and on the context of the Ottoman reforms of the last third of the $19^{\text {th }} \mathrm{c}$. have brought a new vision of the late Ottoman period. In this article, I try, with the example of urban governance and of municipal institutions, to build on the context of the present dynamism in historiography in order to propose a new reading of the municipality under its late Ottoman form and to propose alternative interpretations to the still widely accepted dichotomy about the transition between Empire and Nation State. The main argument is that there was between at least the $16^{\text {th }}$ and the $19^{\text {th }}$ century an old regime form of urban government in the city, more complex than often described, and that this system was reformed during the second half of the $19^{\text {th }}$ century, when the municipality became one of the instruments of the promotion of an Ottoman modernity. I argue that this Ottoman municipal modernity was consistant and coherent, in spite of its limits, and that a re-evaluation of this feature in necessary in order to revise interpretations about the passage to Greek sovereignty. The imperative of a new perspective on the urban and local nature of the municipal Ottoman modernity invites indeed to pose new questions to the passage to the Greek period.

\section{Cosmopolitan Salonica and the Ottoman governance of diversity: an old regime municipal system}

The city was characterized by the great diversity of its population since Antiquity and by numerous changes in the composition of it. But rather than just describing this diversity as a juxtaposition of communities under the aegis of a more or less external imperial element, it

1 On the context: Hall (Richard),The Balkan Wars (1912-1913): A Prelude to the First World War, London, Routlege, 2002, 192p. 
now seems possible, under the light of recent progresses in Ottoman urban history, specifically in the field of local governance, to propose alternative interpretations to dominant narratives ${ }^{2}$. Such interpretations, based upon a new reading of the relationship between cities and the central power in Istanbul, also invite to revise ideas about the very nature of the Ottoman Empire ${ }^{3}$. Salonica, under Ottoman rule, was indeed a city with a plural population, but also was the object of a typically ottoman form of urban government. It had been the object of the progressive construction of a bureaucratic and ideological apparel which can be called the Ottoman urban old regime. It could also be called a form of cosmopolitanism, as diversity was not only a demographical data but was also the object of a political construction, with the participation of different collective bodies into the general urban system of governance: minorities, in Ottoman old regime Salonica, were granted a certain access to the civic sphere, in spite of limitations pertaining to the very nature of this old regime. The reading of the Ottoman municipal reforms of the years 1850-1890 can't be made accurately without a re-reading of this previously existing system. Modernity indeed, was introduced as a reform of an existing form submitted to new challenges, and not as the importation of solutions inspired from abroad into a local vacuum. This has been illustrated for numerous Ottoman cities now, from Beirut to Tunis, Edirne to Baghdad and Aleppo to Jerusalem, and Salonica, with its local specificities, followed a similar path. This is why old regime Salonica must be submitted to a new interpretative process, at the crossroads between Jewish studies, Greek studies, urban studies and imperial Ottoman studies, all domains which generally work according to separate logics and paths.

Salonica indeed had in old regime times a strong specificity: it was one of the very few cities in the Empire with, at least during some periods, a Jewish majority or at least main minority ${ }^{4}$. Jews were present in the city since the Antiquity. The Romaniote population under the Byzantine Empire was very consistent and in spite of some interpretations of the 1478 Ottoman census which does not mention Jews, it is quite obvious that there were Jews in the city during the first Ottoman period, even before the arrival of a massive Jewish immigration from Spain ${ }^{5}$. When it happened, the Jewish population of Salonica, just like the one of Tunis, Algiers or Tripoli, grew very rapidly, bringing new cultural patterns into the city, for example the influence of the medieval Arabic governance of diversity as experienced in al-Andalus. The new Jewish immigrants also brought in new commercial networks and professional skills, of which local guild took great profit. Among the Jews of Salonica, there were both Sepharads and populations of Eastern European origins ${ }^{6}$. This Jewish element was part of the construction of the old regime Ottoman balance in the governance of diversity: immigration was favoured and Jewish communities were seen by imperial authorities as elements of their

2 On the general interpretative context: Lafi (Nora), Esprit civique et organisation citadine dans l'Empire ottoman, Thèse d'habilitation à diriger des recherches, Aix-Marseille I University, 2011, 323p. ; Barkey (Karen), Empire of Difference : the Ottomans in Comparative Perspective, Cambridge, CUP, 2008, $358 \mathrm{p}$.

3

On this topic : Lafi (Nora), « Petitions and Accommodating Urban Change in the Ottoman Empire”, in: Özdalga (Elisabeth) Özervarlı (Sait) Tansuğ (Feryal) (eds.), Istanbul as seen from a distance. Centre and Provinces in the Ottoman Empire, Istanbul, Swedish Research Institute, 2011, 219p, p.73-82.

4 On diversity in Salonica : Mazower (Mark), Salonica City of Ghosts, Christians, Muslims and Jews (1430-1950), London, Vintage, 2006, 490p.

5 On this dimension: Ben-Naeh (Yaron), Jews in the Realm of the Sultans. Ottoman Jewish Society in the $17^{\text {th }} c$., Tübingen, Mohr Siebeck, 2008, 503p.

6 Benbassa (Esther), Histoire des Juifs sépharades, de Tolède à Salonique, Paris, Seuil, 2002, 470p. Also : Levy (Avigdor), The Sephardim in the Ottoman Empire, Princeton, Darwin Press, 1992. On Jewish communities in the Ottoman Empire : Shmuelevitz (Aryeh), The Jews of the Ottoman Empire in the Late 15 and the $16^{\text {th }} c$., Leiden, Brill, 1984; Robert Olson, «Jews in the Ottoman Empire in Light of New Documents », Jewish Social Studies, 1979, 41-1, p. 75-88, as well as the classic: Franco (Moïse), Essai sur l'histoire des Israélites de l'empire Ottoman depuis les origines jusqu'à nos jours, Paris, Durlacher, 1897. 
building of a city faithful to the Empire ${ }^{7}$. This has long been interpreted as an anti-Greek move: bringing new population into a recently conquered city was an element of the Ottoman strategy of urban control and domination. But it was also something more complex, pertaining to imperial equilibriums at the scale of both the Empire and the city: between forced migrations and implicit invitations to migrations, many cities of the Empire in old regime times were subjected to population changes. The nature of such changes must not be interpreted under the light is similar events in the early $20^{\text {th }} \mathrm{c}$. when ethnic homogeneization responded to new ideologies. In the 16th c. about half of Salonica's population was Jewish. Each Jewish community had its own council (cemaat $)^{8}$. Each Christian community was also granted the right to have communal institutions. The old regime Ottoman urban system allowed such communal institutions, and even favoured them and integrated them into urban governance in delegating to them a number of competences. Communal institutions and the Empire were much more entangled than what has long been thought. The organization of the Jewish communities has been extensively studied, but not enough according to its articulation with the Ottoman imperial sphere. In the Empire, communities were granted a certain degree of autonomy, and many urban issues were dealt with at this scale. Communal governance was in no way only religious: it was an element part of an old regime municipal system, just like other elements like neighbourhoods and guilds. Communities were also part of the collective body of the city and the articulation between this collective body and confessional institutions and assemblies is at the heart of the Ottoman urban form of cosmopolitanism: a system of governance, which did not organize equality, a notion extraneous to the old regime political thought, but managed diversity and integrated it into the imperial sphere. Notables from all communities took part in the city council: Muslims in their own name as heads of notable families, Jews and Christians as heads of their relative cemaat, in the collective name of their relative communities. This Ottoman old regime form of political municipal cosmopolitanism is to be seen in the archives, when for example notables from diverse confessions signed a petition together ${ }^{9}$. The city was in no way a juxtaposition of communities held together only by an imperial governor and a military cast of Janissaries extraneous to urban society, but was also a collective body with a rich civic life, the relevance of which was not only at the level of confessional communities. Guilds, which could be multi-confessional, also had a crucial importance in urban governance. Reading old regime Salonica under this perspective allows one to defy from culturalist visions of the city, and to interpret its imperial belonging in a different way. It was indeed more a negotiated balance between local notables and the centre than just the presence into the city of extraneous elements representing the Empire. Streets and quarters had their urban institutions, and there was above them a general urban assembly of notables which was the interlocutor of the imperial governor. The imperial and the local dimensions were intimately entangled, and local notables, mostly merchants, were part of imperial networks. Their activities spanned at the scale of the whole Empire. The main specificities of this Salonica form of Ottoman old regime cosmopolitanism were linked to the diversity within each community (Jewish and Christian, but also Muslim) and to the fact that confessions and ethnic origins did not necessarily match: the identity map was much more complex than simplistic images derivating from the season of nationalisms have given from the $19^{\text {th }}$ c. onwards. Identity had nuances. Salonica's specificity was also linked to the fact that Muslims were not a majority. The articulation between communal institutions and civic institutions at the scale of the city was reformed different times, for example after the creation of the Talmud Torah Hagadol, in 1520, which headed all Jewish communities. In the $17^{\text {th }}$

7 See: Inalcik (Halil), « Foundations of Ottoman-Jewish cooperation”, in Levy (Avigdor), Jew, Turks, Ottomans, A Shared History, Syracuse, NUP, 2002.

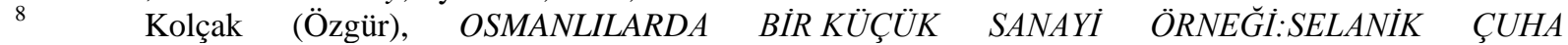
DOKUMACILIĞI (1500-1650), Istanbul University, History Dpt, Licence Thesis, 2005, 133p.

9 BOA, Shikayet, ADVN. 
century, different reforms of the Ottoman old regime organization were also promoted, with the result each time of leading to a renegotiation of local features with urban notables. The question of the Sabbatai Zevi followers also added to the complexity of the situation. But the conversion to Islam in 1686 of many notables of the city following this episode has to be interpreted in the framework of the relationship between local governance and imperial structures. Many notables converted in order to escape Jewish communal justice ${ }^{10}$. The Dönme community ${ }^{11}$ which resulted from this conversion also has to be interpreted according to the general framework of the Ottoman old regime regulating the relationship between the Empire and communal organizations. The balance between communities constituted a kind of imperial Ottoman Pax Urbana and even embodied the very nature of this empire. The equilibrium came to be challenged by new stakes at the turn of the XIXe c., with important consequences on municipal institutions.

The 1826 revolt of the Janissaries, which resulted in months and even years of unrest in the city, is to be analyzed according to such stakes: the entanglement of scales between conflicts at the level of the Empire and local rivalries ${ }^{12}$. The interpretation of this episode must also be made in the context of the various revolts of this kind various cities of the Empire experienced and 1826 in Thessaloniki can be seen as the beginning of the end of the old regime balance of urban faction and communities in relationship to an imperial framework which also included the special prerogatives of a cast of Janissaries the history of which must also be written according to the complexity it was made of. Local historiographies tend to analyze such events mainly under the light of local factors. But instead, there seems to be a relative convergence between such events at the scale of the Empire which might reveal a moment of change in the very organization and logic of it and in the relationship between local elites (and their bodies of urban governance) and the Empire. The Empire and the city were linked not by a dichotomy but instead by complex mutual entanglements.

During the first half of the $19^{\text {th }}$ century, various migration waves as well as the first manifestations of various forms of nationalism also began to challenge the traditional balance between communities. There is of course the context of the Greek independence. But Salonica also became during these decades the nest of diverse forms of nationalism. This represented another challenge to the Ottoman Pax urbana, and a challenge to the old regime municipal system. Here, geopolitical stakes had strong consequences on urban life, down to the scale of every quarter, street and even family. Every wave of migration was also a challenge to the balance of communities and to their representation within old regime forms of municipal institutions ${ }^{13}$. Salonica, moreover, was to be for the next decades a city situated in a region of wars and battles, with here again entanglements of scales between locality and Balkan geopolitics and with the direct impact of war on the city with the arrival of numerous refugees from the Balkans ${ }^{14}$. The Ottoman municipal reforms have to be analyzed in this context, just like the ones in Tripoli of Libya or in Tunis have to be analyzed in the context of the French colonial occupation of Algeria: geopolitics had a strong impact on urban politics and on the very organization of the Empire. In cities of the Empire, the municipal reforms were an imperial response to new threats on local equilibriums and on the very ottomanity of the

10 On justice in Ottoman Salonica: Ginio (Eyal), "The Administration of Criminal Justice in Ottoman Salânik (Salonica) during the $18^{\text {th }}$ c.”, Turcica, 1998, 30, p.185-209.

11 See : Baer (Marc), The Dönme. Jewish Converts, Muslim Revolutionaries and Secular Turks, Stanford, Stanford University Press, 2010, 332p.

12 On the context : Üstün (Kadir), Rethinking Vaka-I-Hayriye: Elimination of the Janissaries on the Path to Modernization, Master Thesis, Bilkent University Ankara, 2002, 103p.

13 On the specific question of the Roma population: Ginio (Eyal), "Neither Muslims nor Zimmis: The Gypsies (Roma) in the Ottoman State", Romani Studies, 2004, 14-2, p.117-144.

14 Şimşir (Bilâl) (ed.), Rumeli'den Türk Göçleri, Ankara, Türk Kültürünü Araştirma Enstitüsü, 1968 and 1970, 2 vol., 819p. and 832p. 
cities, and first took the form of a negotiation with local notables for the passage of their old regime municipal prerogatives into a new institutional framework.

\section{The Municipality of Salonica in the era of the Ottoman reforms}

Here again this moment has to be interpreted in the context of what happened at the scale of the whole Empire, and not only according to local dynamics ${ }^{15}$. If Salonica was one of the seven test cities for the implementation of the municipal reforms, with cities like Tunis, Jerusalem or Damascus, it is precisely because the stakes there were high for the Empire. It was not necessarily because the local population was thought to be ontologically more prone to understand modernity than that of other cities of the Empire, like has long been said about the municipal experiment in the Pera neighbourhood of Istanbul, but rather because Salonica was one of the most important cities in the Empire and was potentially the object of antiOttoman intrigues.

The era of the municipal reforms in Salonica is generally interpreted according to a top-down logic, with the Empire sending modernist governors to the city in order to enact a modernization programme whose inspiration is seen as foreign. Modernization is often described as a movement of westernization, or europeanization. If inspirations from abroad, and even expertise from abroad was important, interpretations about this era need to be nuanced. The reformative programme was made of both institutional reforms and public works. If historiography now acknowledges the reality and consistence of the Ottoman urban modernization effort in Salonica between 1850 and 1910, the local urban dimension of it is often neglected, as well as aspects pertaining to the definition of a new form of Ottoman imperiality in the city. The question of the Ottoman modernity in Salonica deserves to be inserted into a wider framework of interpretation. The symbol of the opening of this period is the 1858 visit of the Sultan Abdul Mezit to the city. At the end of this same year, a decree created the new municipal institution, with a mayor and a municipal council ${ }^{16}$. Historiography has also underlined the role of Sabri Pacha, starting in 1869. The installation of the reformed municipality happened in this context of a special imperial attention: but not of a uniquely top-down process. Local notables were part of the negotiation during all phases, with episodes of conflict and negotiation. The Ottoman imperial pact with local elites was renewed ${ }^{17}$. The problem is that the birth of the Ottoman reformed municipality is often interpreted in the context of a certain underestimation for what there was before. Meropi Anastassiadou, for example, states that before the reforms, "there was no municipal body, nor any will of global governance of urban affairs. Administration was atomized and its only aim was to ensure peace, fight injustices and provide for a regular entry of taxes" ${ }^{\prime 1}$. This is a paradox: ensuring civic peace, social justice and fiscal efficiency is already a huge achievement for something which is not even an administration. And appreciations have to be revised about it. Reforms, indeed, were reforms, and not the creation of something new in an institutional vacuum. The reforms, in Salonica just like in all other Ottoman towns, were implemented in the context of the existence of a strong old regime urban administration. The authority of local notables was reinforced, just like their control over the urban territory through neighbourhood institutions.

\footnotetext{
15 For the context: Lafi (Nora) (ed.), Municipalités méditerranéennes: les réformes urbaines ottomanes au miroir d'une histoire comparée, Berlin, Klaus Schwarz, 2005, 365p.

$16 \quad$ BOA, A.\}MKT.MHHM 430201285 N 04 (19.12.1868).

17 On the renewed support of Jewish notables to the Empire: Cooperman (Eugene), Turco-Jewish Relations in the Ottoman city of Salonica (1889-1912): Two Communities in Suppport of the Ottoman Empire, New-York University, 1991, 642p.

18 Anastassiadou (Meropi), Salonique, 1830-1912. Une ville ottomane à l'âge des réformes, Leiden, Brill, 1997, 465p., p.137.
} 
The communal organizations of the various confessional communities remained important ${ }^{19}$. The council of the notables and elders was formalized in a new way, that of a municipal council, on the same social and functional basis. The 1869 creation of the modern municipality, a few weeks after the 1868 decree, is only the consecration of two decades of reforms and the result of a long negotiation with local notables ${ }^{20}$. Not the importation into an empty shell of a foreign inspiration. As for the modernization programme, a new reading of the relationship between mayor and governors is also to be made. Of course, the new municipality had to struggle from the very beginning for its financial independence, and archives in Istanbul show that most of the correspondence between the mayor of the city and the ministry was about the insufficient budget allocated to the institution and about the limits of its capacity to collect taxes ${ }^{21}$. But the municipality, beyond this matter of fact, was the expression of a dynamic civic life, the nature of which had been deeply modernized. The 1877 imperial law on municipalities also provided partial answers to the early limitations ${ }^{22}$. The situation in 1880 or 1890 can't be analyzed under the only light of the tensions of the turn of the $20^{\text {th }} \mathrm{c}$.

A modernization programme, generally interpreted as directed by governors, transformed the city space, with for example the destruction of the city walls during the 1870's (Wernieski's plans of the walled city date back to this period), with the construction in 1870 of the promenade on the seaside, of the avenue Sabri Pacha (today Venizelos) and of Midat Pasha Street (Today Saint Demetrios) ${ }^{23}$. The 1871 station and the 1875 Municipal Hospital are also symbols of this great programme of public works, just like the modernization of the harbour during the 1880's and the opening at the end of this decade of the first tramway line. Salonica was also connected to the Balkans, with the railway line to Belgrade in 1888 and the one to the capital city Istanbul in 1896.

There is a necessity today to interpret this considerable effort of modernization, comparable to what happened in Beirut, in the context of the reform of local governance, and not only as external imperial impulses being applied to the city with recourse to foreign expertise. The central archives of the Ottoman Empire in Istanbul, where numerous documents about the municipality of Salonica are kept, show that the functioning of this institution was, between the 1870's and the Balkan Wars, that of a modern municipality ${ }^{24}$. The career of municipal engineer Wernieski is an invitation to revise views on this process, for example, just like the study of the negotiations between imperial representatives (themselves often urban notables from different cities of the Empire) and local notables and landowners. Wernieski (also known as Vrenski in Ottoman documents) supervised the preparation of a map of the city by the municipal technical services ${ }^{25}$. Very early during the era of reforms moreover, these municipal technical services launched a process of modern town planning, in which municipal engineers, in connection with landowners and investors, were very active ${ }^{26}$. During the last decades of Ottoman rule, this trend was reinforced, the municipal services facilitating

19 For a testimony on this dimension: Rodrigue (Aron) Abrevaya Stein (Sarah) (eds.), A Jewish Voice from Ottoman Salonica: the Ladino Memoir of Sa'adi Besalel a-Levi (1820-1903), Standford University Press, 2012, 432p.

Ergin (Osman Nuri), Mecelle-I Umûr-i Belediyye, Istanbul, Istanbul Büyüksehir Belediyesi,, 1995(1 ${ }^{\text {st }}$ edition 1914-1922), 8 vol.

$21 \quad$ For example: BOA, A.\}MKT MHM 476651291 B 17 (29.08.1874). In this file, a request by mayor Faik Bey for more budget in order to pay municipal employees is to be found.

22 BOA, MAD. d1065. Maliyeden Müdevver Deftere. The case of Salonica was treated together with those of cities like Aleppo, Tripoli or Beirut. See also: BOA, I..MVL.204 62221867 CA 24 (28.3.1881)

23 On the programme of public works: BOA, I.MVL.00522 234671281 b 26 (1.12.1864).

$24 \quad$ For example, about mayor Ibrahim Bey: BOA, BEO $8563511310 \mathrm{Ra} 18$ (9.10.1892). The file BEO 90 $64491310 \mathrm{Ra} 27$ (18.10.1892) provides the correspondence between the municipality and the ministry in Istanbul.

$25 \quad$ BOA, Y..MTV.2972 1305 R 09 (3.1.1888).

26 About these early steps in modern planning: BOA, A\{AMKT.16633 1265 S 1 (29.12.1848). 
investment in new neighbourhoods by investors often belonging to the Christian and Jewish communities $^{27}$. It is the same for the interpretation of the role of foreign technical expertise and investment. Salonica, just like all major Ottoman cities, benefited from the work of the best engineers on the European and Mediterranean market, a fact which is not a sign of submission to an external order by rather of insertion into dynamic networks. The system of the concession, which was chosen for the implementation of the modernization programme of numerous public services, has to be interpreted according to a similar logic. It was accompanied by the growth of the municipal technical apparel. The position of municipal engineer in Salonica was very attractive on the international market of expertise.

In the case of water for example, the 1888 concession to a Belgian Firm and to the investor Nemli-Zade Effendi Chamdi, under the name of Compagnie Ottomane des Eaux de Thessalonique, was a sign of the close relationship between local interest, municipal civic conscience, European capitalism and imperial logics. The work of engineer Campion is to be read in this context. Public fountains were built in all major streets of the city, just like in all Ottoman cities, and were a sign of the civic municipal and social dimension of the modernization programme. They were also a sign of the imperial pact with local elites. Municipal engineers in Salonica were very active, and were also inserted into the Ottoman network of municipal connections, with other cities of the Empire.

A new interpretation of this period is emerging: it was not necessarily a westernization, but a true Ottoman modernization. Many new neighbourhoods were built, and the age of the Ottoman reforms was a period of strong urban dynamism for the city. Entrepreneurs, often belonging to the Christian and Jewish parts of the population, took profit of the new political and regulatory context (limitations on landownership by Christians and Jews outside of the walls -or ex-walls- were lifted) in order to launch ambitious urban projects. Alexandra Yerolympos illustrated how the municipal technical services were key in planning the extension of the city outside of its traditional limits, with a plan from 1879 and with the municipal acceptance of the 1889 planning initiative by the former municipal engineer Achille Campanakis ${ }^{28}$. The planning of a neighbourhood of social housing for the Jewish community after the 1890 fire was also made in close collaboration with the planning services of the municipality. The public municipal, the communal and the private spheres were linked. The common point was that they were all controlled by the same milieu of notables.

The achievements of mayor Ahmed Hamdi Bey (1893-95 and 1901-1907), a rich Dönme merchant and landowner, also have to be reinterpreted: he was a typical figure of the Ottoman modernity, with strong roots in the old regime past of the city. Both Young Turks and Greeks later diminished his importance, but the fact is that the fin de siècle ottoman municipality was an efficient instrument in the hands of local notables working in the framework a highly imperial ideology of reinvention of the imperial pact with local elites. Not only governors acted for modernization and local society was highly involved, which doesn't mean that the central government was not active ${ }^{29}$.

Architecture is also a symbol of this complexity of the late Ottoman period. Who embodies indeed the Ottoman architectural modernity in Salonica? A Sicilian architect sent by the Ottoman government. This is a typically Ottoman practice, not an exception, and Greek architects were also active in many cities of the Empire ${ }^{30}$. It happened in dozens of other

\footnotetext{
$27 \quad$ Yerolympos (Alexandra), "Thessaloniki (Salonica) before and after 1917: 20 $0^{\text {th }}$ c. Planning versus $20^{\text {th }} \mathrm{c}$. Urban Evolution", Planning Perspectives, 1988, 3-2, p.141-166.

$28 \quad$ Yerolympos (Alexandra), «Formes spatiales d'expansion urbaine et le rôle des communautés nonmusulmanes à l'époque des réformes : Etudes de cas dans les villes des provinces européennes de l'Empire ottoman (1839-1912)», REMM, 107-110, p.113-142.

$29 \quad$ The work of Jens Hanssen on fin de siècle Beirut illustrates similar dynamics.

30 Kolonas (Vasiles) Colonas (Vassilis), Greek Architects in the Ottoman Empire (19th-20 ${ }^{\text {th }}$ c.), Oikos,
} 2005, 155p. 
Ottoman cities and reinforced the imperial image. But once in the city, the figure also worked with and for local elites. Vitaliano Poselli, who was born in the region of Catania and studied architecture in Rome, was first called in Istanbul by the Catholic Church for the restoration of the Santo Stefano Church. He then entered the service of the Ottoman government and was sent to Salonica in 1886 in order to build a school. He remained in the city and built many public buildings, including the one of the Ottoman governorate (wali) in 1891. But he also built churches, synagogues and mosques, sign of his total acceptation by local notables of various communities, and sign that the Ottoman modernity he embodied was carrying shared values.

The work of architect Xenophon Painodis follows the same logic: when working for the endowment by a rich Greek merchant of the city for the construction of the Orphanage under Ottoman municipal auspices, or when building what is now known as Villa Mordoch, he acted in a typically Ottoman way, witnessed in dozens of other Ottoman cities, from Aleppo to Tripoli or Istanbul.

The main question in this reinterpretation is thus not on the nature of modernization, but on the nature of the reformed municipal institutions. The analyze of this nature generally starts with considerations on the absence of any previous form of urban governance emanating from local society. It is of course no longer acceptable. But even the nature of the reformed municipal institutions has to be the object of renewed discussions. Judgments on the absence of urban conscience and absence of true municipal institutions are to be revised as well. The Ottoman municipality had 4 decades of efficient existence, and was able to renew the pact between local elites and the Empire. But it failed on different levels: it was never granted enough financial resources in order to reach a sufficient level of intervention outside of the great operations conducted in conjunction with the governors (but these great operations however changed the city and are to be read outside of a mere top-down scheme, as local notables were partners, not only as landowners, but also as members of the municipal council). And it was not able to invent a system of representation of the diverse identities present in the city that could really substitute that of the old regime with modernity. In other words, it proved an efficient solution in order to renew the imperial alliance between the urban sphere and the Porte, but not in order to invent a modern form of urban cosmopolitan governance.

This failure to invent the Ottoman cosmopolitanism of a new era, in the context of growing nationalist activities of different natures, poses the question of the relationship between the modern municipal idea and the governance of diversity, a question which affects not only the Ottoman municipality, but also the Greek one of the post-1912 period $^{31}$. During the Ottoman era of reforms, the municipality as the urban body of representation of urban diversity was always challenged for its incapacity to both be as ductile as the old form it was a reform of, and be based on a new idea of urban citizenship. It was a half-measure in that sense, and this was its limit. Bulgarian, Greek ${ }^{32}$, Turk and also, in a more marginal way, Zionist ${ }^{33}$ nationalists, were providing a new ideological framework, and relation to the world, which was not easily reducible to municipal coexistence. The last period of Ottoman rule was also

31 For a reflection on urban cosmopolitanism in the age of nationalisms: Davies (Norman) Moorehouse (Roger), Microcosm: Portrait of a Central European City, London, Pimlico, 2003, 585p.; Fuhrmann (Malte) and Kechriotis (Vangelis), « The Late-Ottoman Port-Cities and their Inhabitants: Subjectivity, Urbanity and Conflicting Orders", Mediterranean Historical Review, 2009, 24-2, p.71-78.Vassilikou (Maria), "Greeks and Jews in Salonika and Odessa: Inter-ethnic Relations in Cosmopolitan Port Cities", Jewish Culture and History, 2001, 4-2, p.155-172. Cesarini (David), "Port Jews: Concepts, Cases and Questions", Jewish Culture and History, 2001, 4-2, p.1-11.

32 Dakin (Douglas), The Greek Struggle in Macedonia (1897-1913), Thessaloniki, Museum of the Macedonian Struggle; Institute for Balkan Studies, 1966, 490p.

33 Benbassa (Esther), «Zionism in the Ottoman Empire at the end of the 19th and the beginning of the 20th c. », Studies in Zionism, 1990, 11-2, p.127-140. 
marked by strong conflicts between Greeks and Bulgars ${ }^{34}$. The Ottoman reforms were an attempt in the direction of the invention of a modern form of cosmopolitanism, but not complete enough in order to grant civic harmony. Or maybe not strong enough to counter the winds of nationalism. The difficulty of the Empire to gather consensus on the imperial idea illustrates the limits of the process of Ottoman modernity ${ }^{35}$. But it does not cancel the fact that the reforms were partly successful. The growth of a working class also challenged the old regime style relationship between notables and the population, and the modern municipality did not really address this mutation ${ }^{36}$. On the other hand, in many other cities and countries, the invention of municipal democracy took time, and was often made at the cost of an ethnic homogeneization.

\section{Questions on the passage to municipal governance after the annexation to Greece}

This is why many of the questions on the passage to the Greek municipality are common with those on the Ottoman one. It is not only a question of institutional continuity, but also of common features in front of common challenges. The institutional change is not huge: municipal law in Greece had a lot in common with the one in the Empire: it was designed in a similar cultural context of reform of the same old regime system and was implemented in a negotiation process involving notables from often similar sociological milieux. The challenges the Ottoman municipality had to face remain the same for the Greek one: the governance of diversity, the relationship between a city with a minority in majority and the centre, the financing of modernization, the role of notables, the institutional pact between a local elite of landowners and merchants and the central government.

Many aspects of a certain continuity have to be underlined, from the confirmation of the system of the concession of public service to private operators to the framework of operation of the technical services. Same thing for the operation of municipal social services. As for the question of the governance of diversity within the Greek municipal system between 1912 and World War I, the impression is that of the limits of the municipal instrument to embody a modern form of urban cosmopolitanism. Concerns were already expressed among the Jews during the first weeks and months of Greek rule and negotiations with Jewish notables proved difficult $^{37}$. The heritage of the question of the internationalization of the city remained pressing during the first months, and in spite of guarantees given by the Greek government on the representation of non-Greek communities, the situation remained tensed ${ }^{38}$. Projects for internationalization evoked the hypothesis of a Jewish mayor ${ }^{39}$. These guarantees over the continuation of communal life and on the civic rights of the Jews were more vague as for the

\footnotetext{
34 See, on the 1908 episodes of urban violence between Greeks and Bulgars following the assassination of the Greek consul Askitis: Michailidis (Iakovos), "From Christians to members of an ethnic community: creating borders in the city of Thessaloniki (1800-1912)", in Klusakova (Luda) and Teulières (Laure) (eds.), Frontiers and Identities: Cities in Regions and Nations, Pisa, Plus, 2008, p.169-180. Vermeulen (H.), "Greek cultural dominance among the Orthodox population of Macedonia during the last period of Ottoman rule", in Block (A.) and Driessen (H.) (eds.), Cultural Dominance in the Mediterranean Area, Nijmegen, 1984, p.225-246.

$35 \quad$ Ginio (Eyal), "Mobilizing the Ottoman Nation during the Balkan Wars (1912-1913): Awakening from the Ottoman Dream", War In History, 2005, 12-2, p.156-177.

Quataert (Donald), «The industrial working class of Salonica (1850-1912)», in Levy (Avigdor), Jews, Turks, Ottomans: a shared history, Syracuse (NY), Syracuse UP, 2002, 395p., p.194-211.

$37 \quad$ Molho (Réna), «Popular antisemitism and State policy in Salonika during the city’s annexation to Greece », Jewish Social Studies, 1993, 50-3-4, p.253-264.

38 Molho (Réna), «Salonique après 1912 : les propagandes étrangères et la communauté juive », Revue historique, 1992-1, p.127-140.

$39 \quad$ Gelber (N.M.), “An attempt to internationalize Salonika, 1912-1913”, Jewish Social Studies, $1955,17-$ 2, p.105-120.
} 
implementation of an equal civic representation at the scale of municipal life ${ }^{40}$. Venizelos used the influence of Greek Jews in order to reassure the local Jewish community.

The governance of diversity under Greek rule, during the short period of a situation in which the Greeks were still a minority, is crucial in order to understand the fate of the idea of cosmopolitanism in this city in transition between Empire and Nation State ${ }^{41}$. The 1912-1917 period is fascinating, as we have the situation of a nation-state with one of its most populated cities inhabited by a majority which does not belong to the majority in the country. The fact that urban planning became a central government competence was in this context a first challenge to the municipal sphere and of course to the competences of non-Greek notables ${ }^{42}$. The career and achievement of Osman Sait Ibrahim Chaki have to be looked at under a new light. He was mayor from 1912 to 1916 and then from 1920 to 1922, but decisions on the reconstruction after the 1917 fire, and the fire itself, happened under mayor Konstantinos Angelakis.

Everything changed indeed in 1917. The city (135000 inhabitants), was hit by the Great Fire, an event the interpretation of which has to be made in this framework of tensions. Jewish quarters were mostly affected and the balance of communities in the city was durably modified $^{43}$. The fire marked the beginning of a massive Jewish emigration to the US, to Palestine and to Paris. It also marked a big change in the functioning of the municipality. More than 1912 maybe. Very important is the recourse to expertise external not only the municipality, but also to the municipal sphere for the planning of reconstruction.

Ernest Hébrard (1875-1933) indeed, arrived in Salonica as an archaeologist working for the French troops stationed in Thessaloniki during World War I. He was one of the ideologists of the project of (re)hellenization of the city. The recourse to this expert has nothing to do with what had happened many times between 1850 and 1917: calling a foreign expert for a specific municipal project. The ideological dimension of the project of (re)hellenization of the city, against its Jewish, Turkish and Slavic urban components was already present in the very choice of the expert ${ }^{44}$. The image of a European city as conceived by Hébrard, was an ideological challenge to urban cosmopolitanism, but also to municipal practices of planning as formalized during the late Ottoman period. Hébrard worked in Thessaloniki with Aristotelis Zachos (1871-1939): not a local municipal engineer or architect who would have been working in the municipality since the Ottoman times, but a Greek from Macedonia exiled in Germany and having returned to Greece only in 1905 (and not to Ottoman Salonica).

Zachos came to Thessaloniki in 1913: he draw the master plan, by appointment of the Greek central government, not of the municipality. Between 1915 and 1917, Zachos was head of the planning department of the Athens municipality. He came back to the Macedonian city after the Great Fire. After 1920, Hébrard was sent to Indochina, where he became the official planner of Hanoi for the French colonial administration: he again implemented the planning of a city corresponding to a precise ideological project.

$40 \quad$ Molho (Rena), «The Jewish Community of Salonika and its incorporation into the Greek State (19121919) », Middle-Eastern Studies, 1988, 24-4, p.391-403. See also: Fleming (Katherine), Greece: a Jewish History, Princeton, Princeton University Press, 2010, 271p.

$41 \quad$ For a reflection on the notion of cosmopolitanism in Salonica: Benveniste (Annie), "Salonique, ville cosmopolite au tournant du XIXe siècle", Cahiers de l'URMIS, 2002, 8.

42 On the relationship between the national ideal and urban planning in Greece: Hastaoglou-Martinidis (Vilma), "City form and national identity: urban designs in $19^{\text {th }}$ c. Greece", Journal of Modern Greek Studies, 1995, 13-1, p.99-123.

43 On the context: Vassilikou (Maria), Politics of the Jewish community of Salonika in the inter-war years: party ideologies and party competition, University College London, Doctoral Thesis, 1999, 334p.

On the general ideological context of planning in the region: Yerolympos (Alexandra), "A New City for a New State. City Planning and the Formation of National Identity in the Balkans (1820s-1920s), Planning Perspectives, 1993, 8-3, p.233-257. 
The population exchanges of 1921-22 (20 000 Muslims expelled to Turkey, 160000 Greeks refugees from what had become Turkey installed in Thessaloniki) are also to be read in the context of the challenges on the very nature of the governance of diversity the municipality was the instrument of ${ }^{45}$. Osman Ibrahim Sait Chaki the mayor of the city himself was expelled. The arrival of the Greeks from what had become Turkey changed the city in the same proportions as the arrival from Jews from Spain did a few centuries earlier and poses the same kind of questions on the role of institutions of urban governance. This 1921 moment has indeed to be interpreted as a new municipal transition: Thessaloniki became a city with a Greek majority. Jews became a minority in a system in which the articulation between communal institutions and municipal representation was unclear ${ }^{46}$. The programme of hellenisation which followed, is to be interpreted in relation to the link between planning and ideological visions ${ }^{47}$.

\section{Conclusion: new research perspectives on cities in transition}

The municipal history of Thessaloniki invites to reflect on urban transitions at different levels: it illustrates the importance of the knowledge of the previous situation in order to understand the reformed; it also illustrates the fact that stakes are entangled and that municipal governance was a stake not only of local representation, but also of relationship between local society, central government and the world in general. When analyzing urban transitions, historians tend to exagerate the degree of novelty of the reformed situation. The example of Thessaloniki invites to reinforce attention to previous situations. It is only with a reappraisal of the consistance of the Ottoman urban old regime that adequate interpretations on the reforms of the tanzimat era are possible, and it is only with a reappraisal of the achievements of this era that an understanding of the stakes and processes of passage to Greek sovereignty is possible. You can't understand transitions and underline the true stakes they are the expression of without challenging common views on past situations. As for municipal history, what the Thessaloniki case illustrates is the importance of the old regime heritage, the limits of political modernity for the conceptualization and practice of the governance of diversity, and the tragic end of a cosmopolitanism, which was cancelled before being given the chance of inventing its own modern form.

\footnotetext{
$45 \quad$ On these events: Kontogiorgi (Elisabeth), Population exchange in Greek Macedonia: the rural settlment of Refugees (1922-1930), London, Clarendon, 2006, 380p.; Loizos (Peter), „Ottoman Half-Lives: Long Term Perspectives on Particular Forced Migrations“, Journal of Refugee Studies, 1999, 12-3, p.237-263; Sundhaussen (Holm), Forced Ethnic Migration, European History Online.

46 On this period: Vassilikou (Maria), Politics of the Jewish Community of Salonica in the inter-wars years : party ideologies and party competition, Phd, University College London, 1999, 334p.

$47 \quad$ Hastaouglou-Martinidis (Vilma), “A Mediterranean City in Transition: Thessaloniki between the two World Wars", Facta Universitatis, 1997, 1-4, p.493-507. See also: Mangana (Vassiliki), Westernization and Hellenicity: Form and Meaning in Thessaloniki (1850-1940), University of Michigan, 1995, 674p.
} 